Prawne i ekonomiczne aspekty imigracji do Polski, red. Magdalena Butrymowicz,

Piotr Kroczek, Kraków 2017, s. 7-22 (Biblioteczka Prawa, 2).

DOI: http://dx.doi.org/10.15633/9788374386340.02

Magdalena Butrymowicz

UNIWERSYTET JANA PAWŁA II W KRAKOWIE

\title{
Obywatel, nie obywatel, Polak czy nie Polak, członek Narodu Polskiego czy może obcego? Analiza krytyczna
}

Konstytucja Rzeczypospolitej Polskiej ${ }^{1}$ w swojej preambule odwołuje się do dziedzictwa Pierwszej i Drugiej Rzeczpospolitej Polskiej jako fundamentu i bytu Narodu Polskiego. Powstaje pytanie: co autorzy konstytucji rozumieli pod tym pojęciem? Szczególnie jest to istotne $\mathrm{z}$ tego względu, iż pojęciem tym posługują się w pierwszej osobie: „My Naród Polski”. Pojęcie narodu ma tu zatem charakter polityczno-prawny, pozostając, jakby się wydawało, w oderwaniu od tradycji historycznej czy etnicznego pojęcia narodu ${ }^{2}$. Niemniej jednak autorzy

1 Konstytucja Rzeczypospolitej Polskiej z dnia 2 kwietnia 1997 r., Dz.U. z 1997 r. $\mathrm{Nr} 78$, poz. 483 z późn. zm., dalej: Konstytucja RP z 1997 r.

2 Zob. W. Skrzydło, Konstytucja Rzeczypospolitej Polskiej. Komentarz, Warszawa 2013, s. 23-27. 
preambuły definiują w tym miejscu Naród Polski jako wszystkich obywateli Państwa Polskiego. To wyraźne sprecyzowanie pojęcia Narodu jako obywateli pozwala nakreślić ramy porządku prawnego oraz określić samego prawodawcę, jakim jest naród. Naród rozumiany jest w tym kontekście wyłącznie jako ogół obywateli zamieszkujących na terenie Państwa Polskiego. Pojawia się zatem zaraz na wstępie potrzeba zdefiniowania samego obywatela - kim on jest i jakie jest jego powiązanie $\mathrm{z}$ narodem, jeżeli w ogóle takie istnieje.

\section{Obywatel}

Obecnie na gruncie prawa międzynarodowego odchodzi się od łączenia pojęcia obywatelstwa z pochodzeniem etnicznym. Artykuł 2 Europejskiej konwencji o obywatelstwie z 6 listopada 1997 r. ${ }^{3}$ wskazuje wyraźnie, iż obywatelstwo to więź prawna, która istnieje pomiędzy osobą a państwem. Nie analizując szczegółowo tego dokumentu, wskazać należy, iż w myśl autorów konwencji obywatelstwo powinno stanowić samoistną więź określającą wzajemne prawa i obowiązki. Ta więź ma być całkowicie abstrakcyjna, w oderwaniu od czynnika społeczno-etnicznego. Polski ustawodawca, podobnie jak większość państw europejskich, nie zdefiniował w żadnym akcie prawnym, co konkretnie rozumie pod pojęciem obywatel. W ustawie $\mathrm{z}$ dnia 2 kwietnia 2009 r. o obywatelstwie polskim ${ }^{4}$ ustawodawca w ogóle nie podjął się, nawet w sposób opisowy, wskazania, co rozumie pod tym pojęciem, przechodząc od razu do sposobów i trybów nabycia

3 European Convention on Nationality, Strasbourg, November 6, 1997, European Treaty Series, No. 166. Polska nie ratyfikowała tej konwencji.

4 Ustawa z dnia 2 kwietnia 2009 r. o obywatelstwie polskim, Dz.U. z 2012 r., poz. 161 z późn. zm. 
obywatelstwa ${ }^{5}$. Również w komentarzu do przedmiotowej ustawy nie znalazła się nawet wzmianka na ten temat ${ }^{6}$. Wyłącznie we wprowadzeniu autor w sposób ogólny próbuje opisać, jak należy rozumieć to pojęcie na gruncie akademickim i praktycznym ${ }^{7}$.

Pojęcie obywatelstwa jest zatem takim terminem prawnym, który ogólnie jest rozumiany przez wszystkich jako katalog wzajemnych praw i obowiązków, a w niektórych przypadkach jako synonim więzi narodowo-etnicznej danej grupy.

Międzynarodowy Trybunał Sprawiedliwości (dalej: MTs) w orzeczeniu w sprawie Liechtenstein przeciwko Gwatemali (Nottebohm) ${ }^{8}$ jednoznacznie uznał, iż sprawa obywatelstwa jest w wyłącznej jurysdykcji krajowej poszczególnych państw ${ }^{9}$. W przedmiotowym orzeczeniu MTs ustanowił tak zwaną zasadę Nottebohma, zgodnie z którą obywatelstwo nie jest więzią czysto prawną, która istnieje pomiędzy jednostką a państwem, ale obrazuje także takie aspekty związku jednostki z państwem jak poczucie tożsamości, więzy rodzinne czy pochodzenie etniczne. Zgodnie z zasadą Nottebohma jednostka musi udowodnić realną więź z danym krajem, aby obywatelstwo było skutecznie nadane/otrzymane. Analizując stan faktyczny sprawy,

5 „Obywatelstwo polskie nabywa się: 1) z mocy prawa; 2) przez nadanie obywatelstwa polskiego; 3) przez uznanie za obywatela polskiego; 4) przez przywrócenie obywatelstwa polskiego" - art. 4 ustawy z dnia 2 kwietnia 2009 r. o obywatelstwie Polskim, Dz.U. z 2012 r., poz. 161 z późn. zm.

6 Zob. J. Jagielski, Obywatelstwo polskie. Komentarz do ustawy, Warszawa 2016, s. $49-52$.

7 Zob. J. Jagielski, Obywatelstwo polskie..., dz. cyt., s. 14-17.

8 International Court of Justice, Nottebohm (Liechtenstein v. Guatemala), Judgment of 6 April 1955, http://www.icj-cij.org/docket/index.php?sum=215\&p1=3\& p2 $=3 \&$ case $=18 \& p_{3}=5$ (5.03.2017), dalej: Nottebohm (Liechtenstein v. Guatemala).

9 "Nationality is within the domestic jurisdiction of the State, which settles, by its own legislation, the rules relating to the acquisition of its nationality" - Nottebohm (Liechtenstein v. Guatemala). 
wskazać należy, iż spór toczył się pomiędzy państwami o bardzo odmiennej tradycji prawnej. Rząd Gwatemali nie uznał bowiem naturalizacji Fredericka Nottebohma ${ }^{10}$ przez Liechtenstein za skuteczną i jako obywatelowi Niemiec odmówił prawa wjazdu na swoje terytorium. Liechtenstein nie zgodził się z takim stanowiskiem Gwatemali i na forum międzynarodowym domagał się uznania Nottebohma za obywatela Liechtensteinu. мтs przyznał w przedmiotowym sporze rację Gwatemali i analizując sytuację prawną Nottebohma, wskazał na następujące kryteria ważnej naturalizacji: powiązanie z tradycją, kulturą, więzy rodzinne czy zainteresowania społeczne i politycz$n e^{11}$. Niespełnienie tych kryteriów powoduje, że można uznać, iż nie doszło do skutecznego otrzymania obywatelstwa przez daną osobę. A zatem państwo, zachowując pełną autonomię w zakresie określenia kryteriów ważnego obywatelstwa, pozostaje jednak w tym prawie ograniczone przez normy ogólne prawa międzynarodowego ${ }^{12}$.

Podobnie w tej kwestii wypowiedział się Trybunał Sprawiedliwości Unii Europejskiej w orzeczeniu Janko Rottman przeciwko Freistaat Bayern ${ }^{13}$, stwierdzając jednoznacznie, iż zagadnienia dotyczące nadawania lub odbierania obywatelstwa należą do wyłącznej jurysdykcji krajowej państw członkowskich Unii Europejskiej ${ }^{14}$.

10 Przed otrzymaniem obywatelstwa Liechtensteinu posiadał on obywatelstwo Niemiec, którego się skutecznie nie zrzekł.

11 "At the time of his naturalization, does Nottebohm appear to have been more closely attached by his tradition, his establishment, his interests, his activities, his family ties, his intentions for the near future, to Liechtenstein than to any other State?" - Nottebohm (Liechtenstein v. Guatemala).

12 Zob. J. Połatyńska, Prawo do obywatelstwa jako prawo człowieka, „Acta Universitatis Lodziensis" 69 (2009), s. 74.

13 Wyrok Trybunału (wielka izba) z dnia 2 marca 2010 r., Janko Rottman przeciwko Freistaat Bayern, sprawa C 135/o8, ECLI:EU:C:2010:104.

14 „Jednakże do sądu krajowego należy zbadanie, czy decyzja o cofnięciu obywatelstwa przestrzega zasady proporcjonalności co do konsekwencji, jakie pociąga ona 
Jednak oba międzynarodowe sądy pozostają zgodne co do tego, iż państwa nie mogą całkowicie swobodnie decydować w przedmiocie nadawania obywatelstwa danego kraju i muszą się kierować pewnymi nadrzędnymi standardami, aby jednostka miała zapewnioną przynajmniej minimalną ochronę. Przedmiotowe zastrzeżenia obu sądów zostały sformułowane w celu uniknięcia sytuacji, gdy konkretna osoba pozbawiona obywatelstwa zostaje „bezpaństwowcem”. Gwarantem niedopuszczenia takiej możliwości jest uznanie prawa do obywatelstwa jako prawa człowieka. Po raz pierwszy takie spojrzenie na obywatelstwo zawarte zostało w Powszechnej deklaracji praw człowieka z 1948 roku $^{15}$. Zgodnie z art. 15 deklaracji każdy człowiek ma prawo do posiadania obywatelstwa. Prawo to jest dwuwymiarowe. Z jednej strony nikomu nie wolno samowolnie - czyli bez uzasadnienia prawnego - odebrać obywatelstwa, $z$ drugiej strony nikogo nie można zmusić do posiadania obywatelstwa. Każdy ma bowiem prawo do zmiany obywatelstwa wedle swojej woli i swojego uznania ${ }^{16}$. Prawo

za sobą w odniesieniu do sytuacji osoby zainteresowanej w świetle prawa Unii, poza - w razie potrzeby - zbadaniem proporcjonalności tej decyzji w świetle prawa krajowego. A zatem, zważywszy na znaczenie, jakie prawo pierwotne przypisuje statusowi obywatela Unii, w ramach badania decyzji o cofnięciu nadania obywatelstwa należy uwzględnić ewentualne konsekwencje, jakie omawiana decyzja niesie dla osoby zainteresowanej i w razie potrzeby członków jej rodziny w odniesieniu do utraty praw przysługujących każdemu obywatelowi Unii i w szczególności zbadać, czy utrata obywatelstwa jest uzasadniona w stosunku do powagi popełnionego przez tę osobę naruszenia, czasu, który upłynął pomiędzy wydaniem decyzji w sprawie nadania obywatelstwa a wydaniem decyzji o jego cofnięciu, oraz możliwości przywrócenia osobie zainteresowanej jej obywatelstwa państwa pochodzenia”.

15 United Nation, Universal Declaration of Human Rights, CreateSpace Independent Publishing Platform, January 13, 2016. „Każdy człowiek ma prawo do posiadania obywatelstwa. Nie wolno nikogo pozbawiać samowolnie obywatelstwa ani nikomu odmawiać prawa do zmiany obywatelstwa" - United Nation, Universal Declaration of Human Rights, CreateSpace Independent Publishing Platform, January 13, 2016. 
to jednak jest ograniczone prawem państwa, do którego złożono wniosek o przyznanie obywatelstwa. Nie analizując zbyt szczegółowo zagadnienia, można powiedzieć, iż oba podmioty tego wyjątkowego stosunku prawnego nawzajem się ograniczają. Państwo posiada prawo do wprowadzenia wewnętrznych regulacji prawnych normujących zasady przyznawania i odbierania obywatelstwa - równolegle jednostka ma nieskrępowane prawo wyboru obywatelstwa. Państwo nie może jednak odebrać obywatelstwa osobie, która w wyniku takiej decyzji pozostałaby bezpaństwowcem.

Przekładając powyższe zasady na grunt porządku prawnego Polski, przeanalizować należy nie ustawę o obywatelstwie, ale przede wszystkim konstytucję. W art. 1 czytamy bowiem, iż Państwo Polskie jest dobrem wspólnym wszystkich obywateli ${ }^{17}$. To lakoniczne zdanie w powiązaniu $\mathrm{z}$ treścią preambuły pozwala na zdefiniowanie, kim jest polski obywatel, a co za tym idzie - członek Narodu Polskiego. Państwo jest zatem dobrem wspólnym wszystkich, którzy w nim zamieszkują; zarazem państwo ma troszczyć się o dobro swoich obywateli. Przedmiotowa norma prawna stanowi więc gwarancję poszanowania praw i wolności obywateli Państwa Polskiego. Obywatel jest zatem podmiotem uprzywilejowanym, cieszącym się nie tylko wolnością i szeregiem zagwarantowanych praw, ale także posiadającym określone obowiązki względem państwa ${ }^{18}$. Pojęcie obywatela w konstytucji powiązane jest z terminem „Polak”. Ten niedookreślony termin, dla którego występowania w prawie międzynarodowym nie ma uzasadnienia, nigdzie $\mathrm{w}$ doktrynie niezdefiniowany, pojawia się w kilku miejscach w konstytucji oraz w innych aktach prawnych. Źródła tego

17 „Rzeczpospolita Polska jest dobrem wspólnym wszystkich obywateli” - art. 1 Konstytucji RP Z $1997 \mathrm{r}$.

18 Zob. Konstytucja Rzeczypospolitej Polskiej. Komentarz, red. M. Haczkowska, Warszawa 2014, s. 14. 
pojęcia można doszukiwać się $\mathrm{w}$ art. $3^{19}$, zgodnie z którym Polska jest krajem unitarnym. W tym kontekście Państwo Polskie jest postrzegane jako w miarę jednolity etniczne organizm, w którym osoby narodowości polskiej stanowią znakomitą większośćc ${ }^{20}$. Pojęcie to jest zatem powiązane z pojęciem narodu.

\section{Naród}

Ustawodawca polski, posługując się terminem „naród”, odwołuje się do dwóch różnych znaczeń tego terminu. Pierwsze jest znaczenie polityczno-prawne, jak wskazano powyżej, w dalszej części używane zamiennie ze znaczeniem etniczno-tożsamościowym. Takie postrzeganie narodu jako tworu o znaczeniu politycznym pozostaje w ścisłym związku z art. $4^{21}$, który wprowadza zasadę suwerenności narodu. Zgodnie z treścią tego artykułu władzę w Państwie Polskim sprawuje naród postrzegany jako ogół obywateli. Zatem o przynależności do tak rozumianego narodu decyduje fakt posiadania obywatelstwa polskiego $^{22}$. W oderwaniu od kwestii etnicznych naród w takim sensie jest czystą więzią prawną pomiędzy osobą a państwem. Ta sztuczna więź powstaje w wyniku zdarzenia prawnego, jakim jest pozyskanie obywatelstwa - czy to z mocy prawa, na skutek pochodzenia od rodziców mających obywatelstwo polskie, czy wskutek aktu nadania obywatelstwa w procesie naturalizacji. Konstytucji jednak nie jest obce pojęcie narodu w sensie etniczno-kulturowym - w takim

19 „Rzeczpospolita Polska jest państwem jednolitym” - art. 3 Konstytucji RP z 1997 r.

20 Zob. W. Skrzydło, Konstytucja..., dz. cyt., s. 24-30.

21 „Władza zwierzchnia w Rzeczypospolitej Polskiej należy do Narodu. 2. Naród sprawuje władzę przez swoich przedstawicieli lub bezpośrednio" - art. 4 ust. 1 Konstytucji RP z 1997 r.

22 Zob. W. Skrzydło, Konstytucja..., dz. cyt., s. 24-30. 
znaczeniu występuje to pojęcie w art. $6^{23}$. Naród w takim znaczeniu jest postrzegany jako zbiór osób, które łączy pewna więź, jaką jest historia i poczucie pochodzenia od wspólnego przodka, oraz - co najważniejsze - które mówią tym samym językiem.

Antoni Mokrzycki porównuje naród do żywego organizmu. Przyrównuje powstanie narodu polskiego do rozwoju człowieka: początkowo dziecka, dopiero co narodzonego, które rozwija się, dochodzi do dojrzałości, wreszcie osiąga wiek dojrzały. Autor wskazuje także na szereg elementów, które decydują o tym, iż dana grupa osób (gmina, sioło czy plemię) tworzy wspólnotę. Są to: język, wspólne obyczaje i zwyczaje, prawo, historia czy te same przyzwyczajenia kulinarne ${ }^{24}$. Naród posiada zatem swoją tożsamość, zbiór cech charakterystycznych wyłącznie dla niego, niepowtarzalnych w innym narodzie czy społeczności ${ }^{25}$.

\section{Tożsamość narodowa}

Zatem naród wyróżnia od drugiego narodu istnienie pewnej tożsamości etnicznej, która decyduje o odmienności jednego narodu od drugiego ${ }^{26}$. Naród powstaje w ramach pewnego historycznego procesu, rozciągniętego w czasie i wymagającego wspólnego nakładu pracy większej liczby osób. Jednym z podstawowych owoców tego procesu

23 „1. Rzeczpospolita Polska stwarza warunki upowszechniania i równego dostępu do dóbr kultury, będącej źródłem tożsamości narodu polskiego, jego trwania i rozwoju. 2. Rzeczpospolita Polska udziela pomocy Polakom zamieszkałym za granicą w zachowaniu ich związków z narodowym dziedzictwem kulturalnym" art. 6 ust. 1 i 2 (fragm.) Konstytucji RP z 1997 r.

24 Zob. A. Mokrzycki, Polska jako naród i jako państwo: jéj posłannictwo w organizmie świata ludzkości, Poznań 1859, s. 19-29, 55-69.

25 Zob. Zasady ustroju III Rzeczypospolitej Polskiej, red. D. Dudek, Warszawa 20o9, s. 191.

26 Zob. A. Mokrzycki, Polska jako naród..., dz. cyt., s. 19-29, 55-69. 
jest wytworzenie się tożsamości narodu. Proces ten jest inicjowany przez osoby, które łączą wspólne wartości, pewne poczucie więzi i wspólna przeszłość. Rozpoczyna się on w momencie zakończenia się pewnego etapu przemocy (wojny), po którym w fazie pokoju następuje etap kolejny: procesu budowy narodu. Następuje to poprzez stworzenie podwalin pewnej struktury administracyjnej, zaplecza wojskowego czy bazy socjalnej ${ }^{27}$.

Europa charakteryzuje się istnieniem państw narodowych, co oznacza, że naród jest zaczynem państwowości. W początkach XIXII wieku w Europie rozpoczął się proces kształtowania społeczności quasi-państwowej. Powoli odchodzono od tradycyjnych form plemiennych - pojawiło się społeczeństwo hierarchiczne, a także określone grupy interesu, które zaczęły dominować w pewnych dziedzinach życia. Podział na grupy społeczne posiadające różne interesy początkowo pojawił się na zachodzie Europy, a następnie przeniósł się także do Polski, gdzie społeczeństwo powoli ulegało podziałowi na chłopów, mieszczan i szlachtę ${ }^{28}$. W czasach późniejszych podstawową jednostką społeczną kształtującego się Państwa Polskiego była jednostka terytorialna, w ramach której przeplatały się powiązania majątkowe, rodzinne i grupowe. Już w XIV czy Xv wieku zaobserwować można tworzenie się grup społecznych na bazie tradycji czy wspólnego pochodzenia. Przykładem takich wspólnot społecznych mogą być cechy, które tworzyły się w miastach. Przybierając za opiekuna jakieś świętego, cech podkreślał swoje pochodzenie i powiązanie z grupą społeczną, z której się wywodził, starając się wyraźnie odróżnić od innego cechu. Członkowie cechów starali się wyraźnie

27 Zob. C. A. Watson, Nation-building: A Reference Handbook, Santa Barbara 2004, s. $10-11$.

28 Zob. H. Samsonowicz, Dziedzictwo średniowiecza. Mity i rzeczywistość, Wrocław 2009, s. 126. 
podkreślać swój kraj pochodzenia, jak na przykład szewcy w Krakowie. Powstające cechy obierały sobie zatem patrona czy tworzyły strukturę, która wskazywała na kraj ich pochodzenia, np. Norwegowie obierali za patrona św. Olafa, a Polacy - św. Stanisława ${ }^{29}$. W ten sposób powstały społeczności powiązane wspólną tradycją i pochodzeniem. Tworzenie się zrębów narodu polskiego doprowadziło do wytworzenia się państwa narodowego i silnego utożsamiania się społeczności lokalnej z państwem. Początkowo - tak jak wskazano powyżej - państwo utożsamiano ze szlachtą, a w okresie zaborów umocniła się więź tożsamościowa i struktura narodu polskiego.

Tożsamość narodowa jest zatem tym elementem, który łączy jednostkę z określoną społecznością, identyfikuje ją z konkretną kulturą, tradycją i historią; jest także elementem odróżniającym daną grupę społeczną od innych. Możemy zatem wyróżnić tożsamość jednostki oraz tożsamość grupy ${ }^{30}$. Tożsamość narodu będzie zatem specjalnym typem tożsamości grupowej, gdzie wyraźnie określona społeczność wywodzi swoje pochodzenie od wspólnego przodka, identyfikuje się z konkretną historią i tradycją - i to odróżnia ją od innych grup narodowych. W historiografii Polski pojęcie narodu było określane na kilku płaszczyznach: etnicznej, kulturowej, politycznej (naród jako lud, plemię lub państwo). Z czasem pojęcie to oznaczało już tylko państwo i konkretną grupę, którą była szlachta ${ }^{31}$. Historycznie naród był więc utożsamiany z państwem, a każdy obywatel identyfikował się z państwem, które stanowiło dziedzictwo kulturowe. Tożsamość, będąc procesem identyfikacji z grupą, to wewnętrzne odczucie o przynależności do jakiejś zidentyfikowanej grupy, mającej te same

29 Zob. H. Samsonowicz, Dziedzictwo średniowiecza..., dz. cyt., s. 150-154.

30 Zob. T. Paleczny, Socjologia tożsamości, Kraków 2008, s. 37-38.

31 Zob. M. Łuczewski, Odwieczny naród: Polak i katolik w Żmiącej, Toruń 2012, s. $30-33$. 
przyzwyczajenia i wartości. Czasami tożsamość jest postrzegana jako sentyment do pewnych wartości i historii ${ }^{32}$.

\section{Narodowość polska}

W takich realiach społecznych doszło do powstania i uformowania się w miarę jednorodnego pojęcia Narodu Polskiego. Ustawodawstwo współczesne potwierdza dwupłaszczyznową definicję narodu: prawno-polityczną i etniczno-kulturową. Wspomniany już powyżej art. 6 stał się podstawą do przyjęcia ustawy z dnia 7 września 2007 r. o Karcie Polaka ${ }^{33}$. Przedmiotowa ustawa odwołuje się zatem do przywołanej już uprzednio w konstytucji etniczno-kulturowej definicji Narodu Polskiego, gdzie poprzez odniesienie do takich pojęć jak kultura, tradycja czy wspólny język polski ustawodawca podjął próbę zdefiniowania Narodu Polskiego.

Krytyka ustawy o Karcie Polaka, iż posługuje się pojęciami nieostrymi, jest nieuzasadniona - głównie z tego względu, iż pojęcie narodu czy tożsamości jest co do zasady trudno definiowalne. Przyjęcie przez Irenę Wrońską, iż ustawa jest niejasna, bo posługuje się pojęciami „trudno definiowalnymi”, bez podjęcia próby wyjaśnienia, czy

Zob. M. Guibernau, The Identity of Nations, Cambridge 1988, s. 191.

33 „(...) realizując postanowienia Konstytucji Rzeczypospolitej Polskiej w zakresie udzielania pomocy Polakom zamieszkałym za granicą w zachowaniu ich związków z narodowym dziedzictwem kulturalnym, wypełniając moralny obowiązek wobec Polaków na Wschodzie, którzy na skutek zmiennych losów naszej Ojczyzny utracili obywatelstwo polskie, spełniając oczekiwania tych, którzy polskimi obywatelami nigdy wcześniej nie byli, lecz ze względu na swoje poczucie tożsamości narodowej pragną uzyskać potwierdzenie przynależności do Narodu Polskiego, w celu wzmocnienia więzi łączących Polaków na Wschodzie z Macierzą oraz wspierając ich starania o zachowanie języka polskiego oraz kultywowanie tradycji narodowej" - ustawa z dnia 7 września 2007 r. o Karcie Polaka, Dz.U. z 2014 r., poz. 1187 t.j., dalej: ustawa o Karcie Polaka. 
można z treści ustawy czy samej preambuły dokonać wykładni tych pojęć, nie jest prawidłowe i powinno być poddane krytyce ${ }^{34}$. Dokładna analiza preambuły pozwala już na zdefiniowanie kryteriów, którymi posłużył się ustawodawca, podejmując próbę dookreślenia, kto może zostać członkiem Narodu Polskiego: jest to zatem osoba, która zamieszkuje poza terytorium Rzeczypospolitej Polskiej po wschodniej stronie granicy państwa, która czuje się związana z Państwem Polskim dzięki tożsamemu dziedzictwu kulturowemu lub która utraciła obywatelstwo polskie na skutek zmian terytorialnych granic Państwa Polskiego, które miały miejsce po II wojnie światowej. Preambuła odwołuje się także do pojęcia tożsamości, określając ją jako więź emocjonalną z ojczyzną (Państwem Polskim) i pragnienie potwierdzenia istnienia tej więzi. Podobnie tożsamość polska zdefiniowana została $\mathrm{w}$ ustawie o repatriacji ${ }^{35}$. Obie ustawy przewidują prawie takie same kryteria określenia przynależności do Narodu Polskiego - z tym, iż z odmiennymi konsekwencjami prawnymi.

Ustawa o Karcie Polaka wiąże istnienie narodowości polskiej z dwoma powiązanymi elementami: pierwszy to subiektywne odczucie danej osoby o przynależności do Narodu Polskiego, drugi to obiektywne kryteria pozwalające określić tę więź, jak udokumentowanie istnienia tego związku z Narodem czy udokumentowanie pochodzenia poprzez wskazanie, iż choć jedno z rodziców, dziadków lub pradziadków łączył

34 Zob. I. Wrońska, Specyfika pojęcia „przynależność do Narodu Polskiego” w stosunkach międzynarodowych - uwagi na tle realizacji ustawy o Karcie Polaka przez polskie służby konsularne, w: Wybrane zagadnienia współczesnego prawa konsularnego, red. P. Czubik, W. Burek, Kraków 2014, s. 268.

35 „Uznając, że powinnością Państwa Polskiego jest umożliwienie repatriacji Polakom, którzy pozostali na Wschodzie, a zwłaszcza w azjatyckiej części byłego Związku Socjalistycznych Republik Radzieckich, i na skutek deportacji, zesłań i innych prześladowań narodowościowych lub politycznych nie mogli w Polsce nigdy się osiedlić" - ustawa z dnia 9 listopada 2000 r. o repatriacji, Dz.U. z 2014 r., poz. 1392 t.j., dalej: ustawa o repatriacji. 
z Narodem Polskim węzeł prawny, jakim jest obywatelstwo. Subsydiarnie, gdy nie istnieje możliwość udokumentowania pochodzenia, więź emocjonalną można udowodnić poprzez aktywne działanie na rzecz Narodu Polskiego, zachowanie jego kultury i języka ${ }^{36}$. Spełnienie tych przesłanek upoważnia obywatela innego państwa do wystąpienia do polskiego organu konsularnego o wydanie Karty Polaka, która potwierdza przynależność do Narodu Polskiego. Naród Polski jest zatem pojęciem dookreślonym w ustawie poprzez elementy definiowalne: więź emocjonalną - indywidualne odczucie zainteresowanego, które musi udowodnić - albo pochodzenie od przodków, którzy mieli tę więź potwierdzoną przez istnienie węzła prawnego lub przez własne zaangażowanie na rzecz Narodu.

36 „Karta Polaka może być przyznana osobie, która deklaruje przynależność do Narodu Polskiego i spełni łącznie następujące warunki: 1) wykaże swój związek z polskością przez przynajmniej podstawową znajomość języka polskiego, który uważa za język ojczysty, oraz znajomość i kultywowanie polskich tradycji i zwyczajów; 2) 1 w obecności konsula Rzeczypospolitej Polskiej, zwanego dalej „konsulem”, lub w przypadku, o którym mowa w art. 12 ust. 4 - wojewody, albo wyznaczonego przez niego pracownika, złoży pisemną deklarację przynależności do Narodu Polskiego; 3) wykaże, że jest narodowości polskiej lub posiadała obywatelstwo polskie, lub co najmniej jedno z jej rodziców lub dziadków albo dwoje pradziadków było narodowości polskiej lub posiadało obywatelstwo polskie, albo przedstawi zaświadczenie organizacji polskiej lub polonijnej działającej na terenie jednego z państw, o których mowa w ust. 2, potwierdzające aktywne zaangażowanie w działalność na rzecz języka i kultury polskiej lub polskiej mniejszości narodowej przez okres co najmniej ostatnich trzech lat; 4) 2 złoży oświadczenie, że ona lub jej wstępni nie repatriowali się lub nie zostali repatriowani z terytorium Rzeczypospolitej Polskiej albo Polskiej Rzeczypospolitej Ludowej, na podstawie umów repatriacyjnych zawartych w latach 1944-1957 przez Rzeczpospolitą Polską albo przez Polską Rzeczpospolitą Ludową z Białoruską Socjalistyczną Republiką Radziecką, Ukraińską Socjalistyczną Republiką Radziecką, Litewską Socjalistyczną Republiką Radziecką i Związkiem Socjalistycznych Republik Radzieckich, do jednego z państw będących stroną tych umów" - art. 2 ust. 1 ustawy o Karcie Polaka. 
Ustawa zmieniła niedawno swój charakter, gdyż w pierwotnym założeniu jej celem było wspieranie osób pochodzenia polskiego zamieszkałych poza granicami państwa. Obecnie poprzez liczne benefity związane z posiadaniem Karty Polaka państwo zachęca osoby o narodowości polskiej do „połączenia się z Macierzą”.

Ustawa o repatriacji pomimo odmiennego celu, którym jest restytucja zerwanej więzi prawnej członka Narodu Polskiego z Państwem Polskim, posługuje się podobnymi kryteriami. Członkiem Narodu Polskiego jest zatem osoba, która wykaże się stosownym pochodzeniem oraz znajomością polskiego języka, kultury i tradycji ${ }^{37}$. Ustawodawca w tym konkretnym przypadku pominął element więzi emocjonalnej zainteresowanego. Repatriant, który staje się z mocy prawa obywatelem, członkiem Narodu Polskiego w sensie polityczno-prawnym ${ }^{38}$,

37 „1. Za osobę polskiego pochodzenia, w rozumieniu niniejszej ustawy, uznaje się osobę deklarującą narodowość polską i spełniającą łącznie następujące warunki: 1) co najmniej jedno z jej rodziców lub dziadków albo dwoje pradziadków było narodowości polskiej; 2) wykaże ona swój związek z polskością, w szczególności przez pielęgnowanie polskiej mowy, polskich tradycji i zwyczajów. 2. Za osobę polskiego pochodzenia uznaje się również osobę deklarującą narodowość polską, która posiadała w przeszłości obywatelstwo polskie lub co najmniej jedno z jej rodziców lub dziadków albo dwoje pradziadków posiadało obywatelstwo polskie oraz spełniającą warunek określony w ust. 1 pkt 2. 3. Warunek określony w ust. 1 pkt 1 uważa się za spełniony, jeżeli co najmniej jedno z rodziców lub dziadków albo dwoje pradziadków wnioskodawcy potwierdziło swoją przynależność do Narodu Polskiego przez, w szczególności, pielęgnowanie polskich tradycji i zwyczajów” - art. 5 ust. 1-3 ustawy o repatriacji.

38 „Przepisy te określają zasady nabycia obywatelstwa polskiego w drodze repatriacji, przewidując dwa sposoby uzyskania statusu repatrianta. Pierwszy polega na uzyskaniu obywatelstwa polskiego z mocy prawa z dniem przekroczenia granicy przez osobę przybywającą do Rzeczypospolitej Polskiej na podstawie wizy wjazdowej w celu repatriacji (art. 4 ustawy). W drugim przypadku osoba uznana za repatrianta nabywa obywatelstwo polskie z dniem, w którym decyzja o uznaniu za repatrianta stała się ostateczna (art. 16 ust. 3 w związku z art. 41 ust. 4 ustawy)" - wyrok Wojewódzkiego Sądu Administracyjnego w Szczecinie z dnia 26 stycznia 2005 r., sA/Sz 1037/03, orzeczenia.nsa.gov.pl (17.03.2017). 
musi przede wszystkim wykazać się odpowiednim pochodzeniem od osób, które niezaprzeczalnie były już członkiem Narodu i korzystały ze swoich politycznym uprawnień jako suweren. Więź prawna jest zatem bardziej trwała i kreuje konkretną rzeczywistość prawną, nie jest ona całkowicie oderwana od odczucia emocjonalnego, ale w tym przypadku pełni ono rolę drugoplanową i przejawia się wyłącznie $\mathrm{w}$ woli zainteresowanego, który wnosi o uznanie go za repatrianta.

Tym samym zauważalna w konstytucji z 1997 roku dychotomia pojęcia Narodu jest wyraźnie widoczna w obu tych ustawach. Narodowość polska w ujęciu ustawy zasadniczej i dwóch opisanych powyżej ustaw, które na jej bazie zostały wydane, wyraźnie wskazuje, iż Naród Polski należy zawsze definiować w oparciu o dwa faktory: pochodzenie (połączone z pielęgnowaniem tradycji) oraz więź duchową, indywidualne odczucie i przekonanie, iż jest się członkiem Narodu Polskiego ${ }^{39}$.

\section{Podsumowanie}

Podsumowując powyższe rozważania, nie można nie zauważyć założenia twórców konstytucji z 1997 roku, którzy kładli wielki nacisk na rozróżnienie dwóch podstawowych kryteriów klasyfikacji, kto jest narodowości polskiej. Są to: więź emocjonalna i więź prawna. Historycznie takie podejście do narodowości polskiej jest jak najbardziej uzasadnione. Konstytucje okresu międzywojennego, szczególnie tzw. konstytucja marcowa ${ }^{40}$, wskazywały na Naród jako podmiot polityczno-prawny, który powiązany jest więzami kulturowymi i wspólną historią. Podkreślenie tego dualizmu wyraźnie widać

39 Zob. Zasady ustroju..., dz. cyt., s. 191.

40 „Władza zwierzchnia w Rzeczypospolitej Polskiej należy do Narodu” - art. 2 Konstytucji Rzeczypospolitej Polskiej z dnia 17 marca 1921 r., Dz.U. z 1921 r. Nr 44, poz. 267, dalej: Konstytucja RP z 1921 r. 
w preambule, która w podobny sposób, co konstytucja z 1997 roku, odwołuje się do dziedzictwa historii i więzi emocjonalnej ${ }^{41}$. Konstytucja kwietniowa nie posługuje się co prawda pojęciem Narodu, jednak z treści art. 1 można wyczytać odwołanie się do więzi prawnej, którą jest obywatelstwo, oraz tradycji i historii państwa ${ }^{42}$.

Dualizm przyjęty w konstytucji z 1997 roku jest zatem uwarunkowany tradycją konstytucyjną Państwa Polskiego. Naród to bowiem nie tylko więź prawna, ale przede wszystkim więź emocjonalna, kulturowa i historyczna, na którą składa się znajomość języka, praktykowanie tradycji i kultury przodków, których z Państwem Polskim łączyła więź prawna.

\section{Summary}

Citizen, not citizen, Poles or not? Member of polish nation or not?

Roman Dmowski, polish nationalist from interwar period, defined nation as a living body, a mental community, characterize by individual character and ideology. Nation was developing in the same way as human body. As long as a nation has historical and ideological background it existed independent from the states or other nations. The British sociologist Ernest Gellner, in the „Nation and nationalism”, defined nation thought the culture. According to him the culture is this what differential one nation from the other. Gellner created also other theory. His voluntaristic theory defined nation as artificial creation of men who are defined themselves as a nation. Presented paper will analyze the approaching to the definition of the Polish Nation presented in Polish Constitution and polish legal system.

Keywords: nation, citizenship, Poles Card, community

41 „My, Naród Polski, dziękując Opatrzności za wyzwolenie nas z półtorawiekowej niewoli, wspominając z wdzięcznością męstwo i wytrwałość ofiarnej walki pokoleń, które najlepsze wysiłki swoje sprawie niepodległości bez przerwy poświęcały, nawiązując do świetnej tradycji wiekopomnej Konstytucji 3-go Maja (...)" - Preambuła Konstytucji RP Z 1921 r.

Ustawa Konstytucyjna z dnia 23 kwietnia 1935 r., Dz.U. z 1935 r. Nr 30, poz. 227. 